\title{
Composition and properties of bovine milk: A study from dairy farms in northern Sweden; Part I. Effect of dairy farming system
}

\author{
Hasitha Priyashantha, ${ }^{1 *}$ Åse Lundh, ${ }^{1}$ Annika Höjer, ${ }^{2}$ Gun Bernes, ${ }^{3}$ David Nilsson, ${ }^{4}$ Mårten Hetta, ${ }^{3}$ \\ Karin Hallin Saedén, ${ }^{2}$ Anders H. Gustafsson, ${ }^{5}$ and Monika Johansson ${ }^{1}$ \\ ${ }^{1}$ Department of Molecular Sciences, Swedish University of Agricultural Sciences, Box 7015, SE-750 07 Uppsala, Sweden \\ ${ }^{2}$ Norrmejerier Ek. Förening, Mejerivägen 2, SE-906 22 Umeà, Sweden \\ ${ }^{3}$ Department of Agricultural Research for Northern Sweden, Swedish University of Agricultural Sciences, SE-901 83 Umeå, Sweden \\ ${ }^{4}$ Computational Life Science Cluster, Department of Chemistry, Umeå University, SE-901 87 Umeå, Sweden \\ ${ }^{5}$ Växa Sverige, Ulls väg 26, SE-750 07 Uppsala, Sweden
}

\section{ABSTRACT}

This study was part of a larger project that aimed to understand the causes for increasing variation in cheese ripening in a cheese-producing region in northern Sweden. The influence of different on-farm factors on raw milk composition and properties was investigated and is described in this paper, whereas the monthly variation in the milk quality traits during $1 \mathrm{yr}$ is described in our companion paper. The dairy farming systems on a total of 42 dairy farms were characterized through a questionnaire and farm visits. Milk from farm tanks was sampled monthly over $1 \mathrm{yr}$ and analyzed for quality attributes important for cheese making. On applying principal component analyses to evaluate the variation in on-farm factors, different types of farms were distinguished. Farms with loose housing and automatic milking system (AMS) or milking parlor had a higher number of lactating cows, and predominantly Swedish Holstein (SH) breed. Farms associated with tiestalls had a lower number of lactating cows and breeds other than SH. Applying principal component analyses to study the variation in composition and properties of tank milk samples from farms revealed a tendency for the formation of 2 clusters: milk from farms with AMS or a milking parlor, and milk from farms with tiestall milking. The interaction between the milking system, housing system, and breed probably contributed to this grouping. Other factors that were used in the characterization of the farming systems only showed a minor influence on raw milk quality. Despite the interaction, milk from tiestall farms with various cow breeds had higher concentrations (g/100 g of milk) of fat (4.74) and protein (3.63), and lower lactose concentrations (4.67) than milk from farms with predominantly $\mathrm{SH}$

Received September 16, 2020.

Accepted March 15, 2021.

*Corresponding author: hasi.tvp@slu.se cows and AMS $(4.32,3.47$, and $4.74 \mathrm{~g} / 100 \mathrm{~g}$ of milk, respectively) or a milking parlor $(4.47,3.54$, and 4.79 $\mathrm{g} / 100 \mathrm{~g}$ of milk, respectively). Higher somatic cell count $\left(195 \times 10^{3} / \mathrm{mL}\right)$ and lower free fatty acid concentration $(0.75 \mathrm{mmol} / 100 \mathrm{~g}$ of fat) were observed in milk from farms with AMS than in milk from tiestall systems (150 $\times 10^{3} / \mathrm{mL}$ and $0.83 \mathrm{mmol} / 100 \mathrm{~g}$ of fat, respectively). Type of farm influenced milk gel strength, with milk from farms with predominantly $\mathrm{SH}$ cows showing the lowest gel strength $(65.0 \mathrm{~Pa})$, but not a longer rennet coagulation time. Effects of dairy farming system (e.g., dominant breed, milking system, housing, and herd size) on milk quality attributes indicate a need for further studies to evaluate the in-depth effects of farm-related factors on milk quality attributes.

Key words: farm management factor, milking system, dominant breed, raw milk quality, milk coagulation property

\section{INTRODUCTION}

Raw milk composition and properties are crucial in controlling dairy product quality. Variation in the quality attributes of the raw milk affects different functional properties (Kailasapathy, 2015), and in cheese manufacturing, the characteristics of the resulting cheese rely on the composition and properties of the raw milk (Skeie, 2007; Guinee and O'Brien, 2010). During the last decades, dairy farming has been characterized by rapid intensification, moving toward fewer and larger farms, and, at the same time, increased efficiency and productivity (Clay et al., 2020). The intensification has been characterized by increasing adoption of novel technologies (e.g., for breeding), increased mechanization in feeding, and increased use of robotic milking systems. This transition is also characteristic for dairy production in northern Sweden, to an extent where it has become important to assess how changes in onfarm management and practices may have influenced 
the properties of the milk in this region. In a recent study, the increasing variation in maturation time of a traditional Swedish cheese produced in the region was visualized using hyperspectral image analysis, underlining a need to identify factors contributing to the variation in ripening (Priyashantha et al., 2020).

Milk coagulation properties are reported to be correlated with several milk quality attributes (Glantz et al., 2010; Priyashantha et al., 2019), which in turn are known to be influenced by breed and different on-farm factors (e.g., the type of milking system). The higher milking frequency associated with automated milking systems (AMS), has been suggested to influence several milk compositional parameters compared with milking parlor or tiestall milking (e.g., lower fat and protein content; Løvendahl and Chagunda, 2011), longer rennet coagulation time (RCT) and higher levels of free fatty acids (FFA; De Marchi et al., 2017; Wiking et al., 2019), as well as lower plasmin and plasminogenderived proteolytic activity (Johansson et al., 2017).

The dairy farming system in northern Sweden is an interesting case for comparison with dairy farming systems in other regions in Sweden and Europe. The region where this study was conducted is characterized by boreal forests, scattered landscape, and forage-based agriculture. The region has a subarctic climate with short and fairly warm summers as well as lengthy and freezing winters. Dairy farms in the region deliver their milk to a cheese-making plant to produce a characteristic long-ripening Swedish cheese. Dairy farming is characterized by year-round calving, and during the last decade, the increase in the proportion of farms using AMS was above the average for Sweden. During the same period, there was a transition from tiestalls toward loose housing, as well as an increase in the proportion of farms with Swedish Holstein (SH) as the dominant breed. This study aimed to investigate the variation in the composition and properties of raw milk intended for the production of long-ripening hard cheese in a region in northern Sweden. This first part of the study evaluated the effects of different farm factors on the quality traits of the milk. In a companion paper (Priyashantha et al., 2021), we describe how the milk quality traits are influenced by monthly variation over $1 \mathrm{yr}$ in the region, which was not well explored in previous studies.

\section{MATERIALS AND METHODS}

\section{Experimental Design and Milk Sampling}

The study was part of a full-scale commercial cheese manufacturing trial, using farm milk samples collected monthly during the period February 2016 to February 2017. The participating farms were located in a region between $64^{\circ} 2^{\prime}$ to $65^{\circ} 0^{\prime} \mathrm{N}$ and $19^{\circ} 3^{\prime}$ to $21^{\circ} 5^{\prime} \mathrm{E}$ in the county of Västerbotten. At the beginning of the study, all dairy farmers delivering milk to the participating cheese-making plant were asked about their willingness to participate in the study. A total of 37 farms agreed and were recruited for this study. An additional 5 organic milk production farms that delivered their milk to another milk-processing plant in the region were also included, making a final total of 42 farms. During autumn 2015, the participating farmers were asked to fill out a questionnaire about on-farm management factors, covering feed production and feeding facilities, housing and milking systems, and routines for milking and cleaning of the equipment. Herd and individual animal data (i.e., breed and milk yield) were obtained from the Swedish cow-recording scheme (Kokontrollen, 2016). The farms were visited on 2 occasions during the sampling period, in February and March (indoor period) and July (outdoor period), for an update on feeding, milking, and cleaning routines. The influence of monthly variation on the characteristics of the milk samples is described in a companion paper (Priyashantha et al., 2021). During the study, a few monthly values for 2 farms that decided to end their milk production were excluded. In total, between 296 and 505 of the collected farm milk samples were analyzed for the different milk quality attributes described in this paper. Not all samples were analyzed for all milk quality parameters at every sample collection due to various practical reasons, resulting in varying numbers of analyses per milk quality attribute.

Once every month over a period of $1 \mathrm{yr}$, an extra $250 \mathrm{~mL}$ of milk was sampled by the tanker driver from each farm on the same occasion as the sample routinely collected for raw milk quality control at the official milk testing laboratory (Eurofins Steins Laboratory, Jönköping, Sweden). The extra milk samples were transported separately at $4^{\circ} \mathrm{C}$ to the Department of Molecular Sciences, Swedish University of Agricultural Sciences (SLU), Uppsala for analysis of additional quality traits. Upon arrival, the $\mathrm{pH}$ of milk samples was measured using a pH meter (Seven Compact S210, Mettler-Toledo). We conducted $\mathrm{pH}$ measurements at room temperature after letting samples equilibrate for $1 \mathrm{~h}$. Casein micelle size and rennet-induced coagulation properties were analyzed in fresh skim milk samples. All analyses were performed in the same sequential order on all occasions. Milk samples were then aliquoted and stored at $-80^{\circ} \mathrm{C}$ for analyses of plasmin and total proteolysis (measured as free amino terminals). 


\section{Raw Milk Gross Composition, SCC, and Bacteria}

Raw milk samples were routinely analyzed for gross composition at the official milk testing laboratory, which used Fourier-transform infrared spectral analysis to measure the content of total fat, protein, lactose, urea, and FFA (CombiFoss 6000, Foss). The SCC was routinely analyzed by flow cytometry (Fossomatic, Foss) and total bacteria count using BactoScan FC (Foss Electric). Additionally, starting in May 2016, thermoresistant bacteria were analyzed at Eurofins by a culturing method (Wehr and Frank, 2004).

\section{Casein Micelle Size}

Casein micelle size was determined by nanoparticle tracking analysis (NTA) using NanoSight NS500 (Malvern Instruments) according to the method described by Priyashantha et al. (2019). The system was coupled to a temperature sensor, stage controller, and syringe pump (Harvard Apparatus) fitted with a 1-mL syringe filled with 2,000-fold diluted skim milk. Recorded video clips captured using a camera fixed at $90^{\circ}$ angle and $658 \mathrm{~nm}$ wavelength were batch-processed using NanoSight 2.3 NTA. Average casein micelle size, mode, and standard deviation were determined for each sample analyzed.

\section{Rennet-Induced Gelation}

Rennet-induced coagulation properties of skim milk samples were evaluated using a Bohlin CVOR-150-900 rheometer (Malvern Instruments Nordic AB) according to the method described by Johansson et al. (2015). In brief, calf rennet ( $75 / 25$ chymosin/bovine pepsin, 180 international milk clotting units (IMCU), Kemikalia) was added to the skim milk at a concentration of 0.18 $\mathrm{IMCU} / \mathrm{mL}$. The time of rennet addition was recorded as the start time, and gel formation was monitored. Coagulation properties were measured as RCT (i.e., time in seconds from the point of enzyme addition until a gel strength of $1 \mathrm{~Pa}$ was reached) and gel strength (in $\mathrm{Pa}$ ) 20 min after rennet addition (G20). Each milk sample was analyzed in duplicate.

\section{Plasmin Activity}

Plasmin- and plasminogen-derived activities were determined according to the method described by de Vries et al. (2016). In brief, plasmin and plasminogen were dissociated from casein micelles by incubation of defatted milk with $\varepsilon$-amino- $n$-caproic acid, followed by ultracentrifugation (Beckman Coulter, Inc.). Plasmin activity was measured in the resulting milk serum using $2.5 \mathrm{mg} / \mathrm{mL}$ of a chromogenic substrate, pyroGlu-Phe-Lys- $p$-nitroanilide hydroxy chloride (Aniara, West Chester). Plasminogen activity was derived after activation with urokinase (49.5 plow units) using a multimode microplate reader (FLUOstar Omega, BMG Labtech) at $37^{\circ} \mathrm{C}$. Absorbance was recorded every 3 min for $120 \mathrm{~min}$, and activity was expressed as a change in absorbance at $450 \mathrm{~nm}$ per unit time $(\Delta \mathrm{A} 405 / \Delta \mathrm{t})$. Each milk sample was analyzed in duplicate.

\section{Total Proteolysis Measured as Free Amino Terminals}

Total proteolysis was measured by a fluorescamine method based on the reaction of primary amino groups of trichloroacetic acid-soluble peptides and free AA with fluorescamine, as described by Wiking et al. (2002) and modified by Johansson et al. (2017). In short, milk samples were mixed with an equal volume of $24 \%$ trichloroacetic acid and kept on ice for $30 \mathrm{~min}$ before centrifugation at $16,000 \times g$ for $20 \mathrm{~min}$ at $4^{\circ} \mathrm{C}$. The supernatant $(20 \mu \mathrm{L})$ was mixed with freshly made sodium tetraborate $\mathrm{pH} 8$, fluorescamine was added, and the mixture was loaded in a 96-microwell plate. Fluorescence was measured after $23 \mathrm{~min}$ in a Perkin-Elmer LS55 luminescence spectrometer (Waltham) at excitation wavelength $390 \mathrm{~nm}$ and emission wavelength 480 $\mathrm{nm}$. The extent of proteolysis was expressed as leucine equivalents (eq. $\mathrm{m} M$ ), based on a standard curve with 5 different concentrations $(1,0.75,0.5,0.3$, and $0.05 \mathrm{mM})$ of $0.1 \mathrm{M}$ L-leucine dissolved in $1 \mathrm{mM} \mathrm{HCl}$. Each milk sample was analyzed in triplicate.

\section{Statistical Analysis}

Principal component analysis (PCA; Wold et al., 1987) was used to explore the variation between the 42 farms and their milk sample characteristics. All farm data collected were subjected to a preliminary screening using multivariate analysis to identify the most influential on-farm factors. All types of variation (i.e., both farm and milk variables) were considered for the model, and representative on-farm factors were selected based on their location in the PCA loading plot (Figure 1). Remaining redundant factors were not further considered in statistical models; however, some of the factors were still of interest for the interpretation of overall results. One farm, the only one with Jersey as the main dairy breed, was excluded from the PCA (except when characterizing farms in Figure 2) and all further multivariate analyses. This herd was deemed as an outlier as all its observations were more than 2 standard deviations from the multivariate mean using the Hotelling T2 statistic (Jackson, 1991). One milk sample 


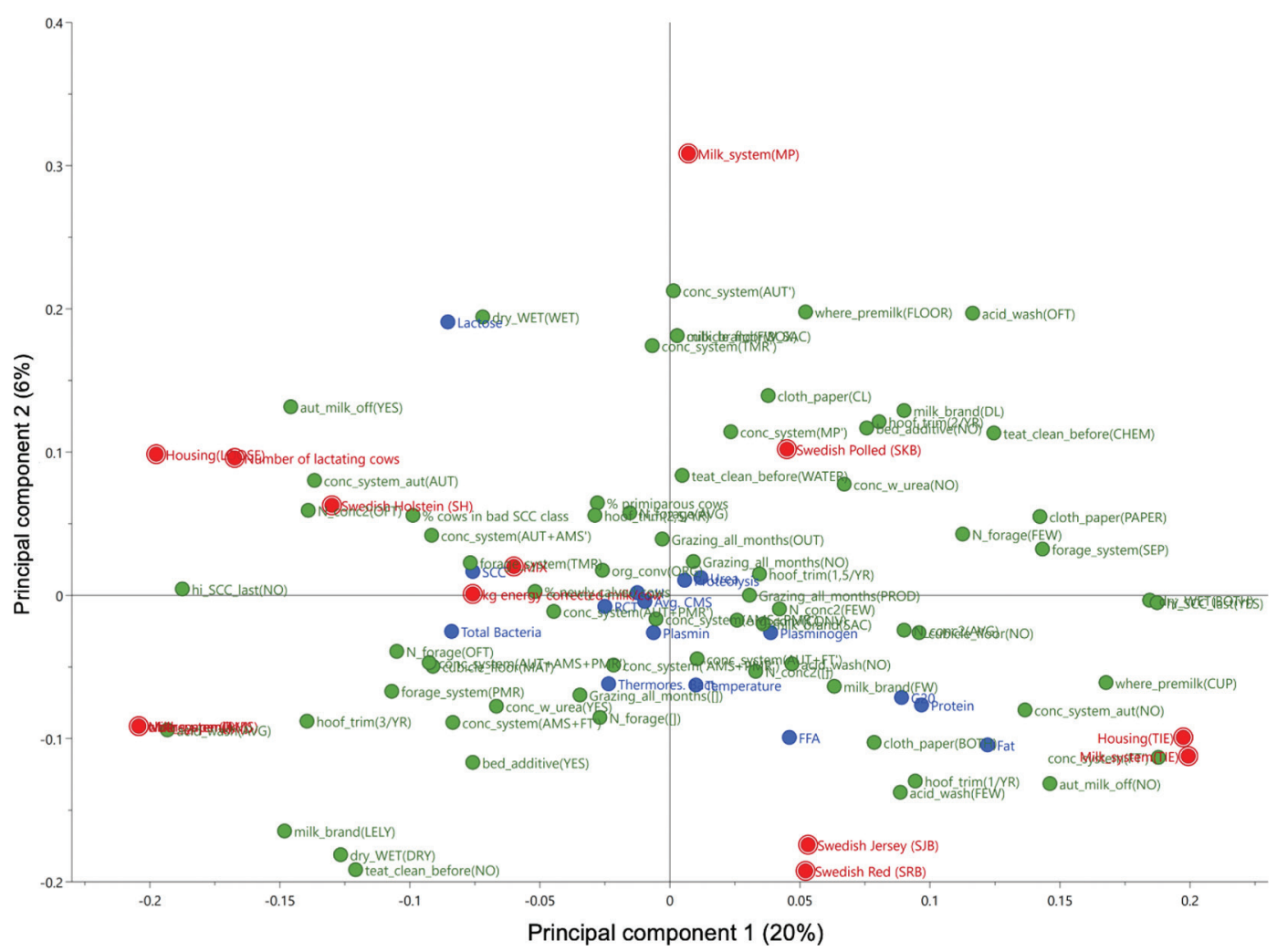

Figure 1. Principal component analysis (PCA) of on-farm (green labels) and milk quality (blue labels) variables used for selection of on-farm factors for further analysis; variables selected for further analysis are denoted with the red label. All data considered in this PCA are listed in Supplemental File S1 (https://dataverse.harvard.edu/dataset.xhtml?persistentId=doi:10.7910/DVN/WKFDIJ).

from another farm, collected in April, was also deemed a serious outlier, as it was more than 4 standard deviations from the multivariate mean.

For the multivariate analysis, 15 variables reflecting milk quality attributes were assembled in a matrix comprising all monthly variables for the 41 remaining farms. The variables were preprocessed with mean centering, and each was set to unit variance by multiplication by its inverse standard deviation. Additionally, the following milk properties were logarithmically scaled (base 10) to adjust for skewness: total bacterial count, thermoresistant bacteria count, FFA, and SCC. We used PCA to compress the multidimensional data into a few principal components using the software Simca 16.0 (Sartorius Stedim Data Analytics AB). This model was restricted to variations associated with milk quality, with on-farm factors used only for interpretation of the results. The PCA score vectors were visualized in 2-dimensional scatter plots to assess similarities, trends, and groupings for the farms investigated. The PCA loading vectors were also used in 2-dimensional scatter plots to display similarities or differences between the milk quality attributes and to interpret the score scatter plots.
Univariate analysis was performed using NCSS 9 (NCSS Statistical Software) and repeated-measures ANOVA, and differences were considered significant at $P<0.05$ using the Tukey-Kramer post hoc test. For univariate analysis, dependent variables (15 variables reflecting milk quality attributes) from all monthly values of all participating farms $(\mathrm{n}=42)$ were evaluated according to the independent variables milking system and dominant breed, respectively. The model took the following form:

$$
Y_{i j k l}=\mu+\alpha_{i j}+\beta_{j}+\gamma_{k}+(\beta \gamma)_{j k}+e_{i j k l}
$$

where $Y_{i j k l}$ is the response (dependent variable) for observation $l$ in farm $i$ (1-42), with milking system $j$ (AMS, milking parlor, or tiestall) on months $k$ (February 2016-February 2017); $\mu$ is the general mean; $\alpha_{i j}$ is the random effect of farm $i$ within milking system or breed $j ; \beta_{j}$ is the effect of the milking system or breed $j ; \gamma_{k}$ is the effect of month $k ;(\beta \gamma)_{j k}$ is the interaction between the milking system or breed $j$ and month $k$; $e$ is a random residual. The farm was used as an error term for testing the significance of the milking system or breed effects. 


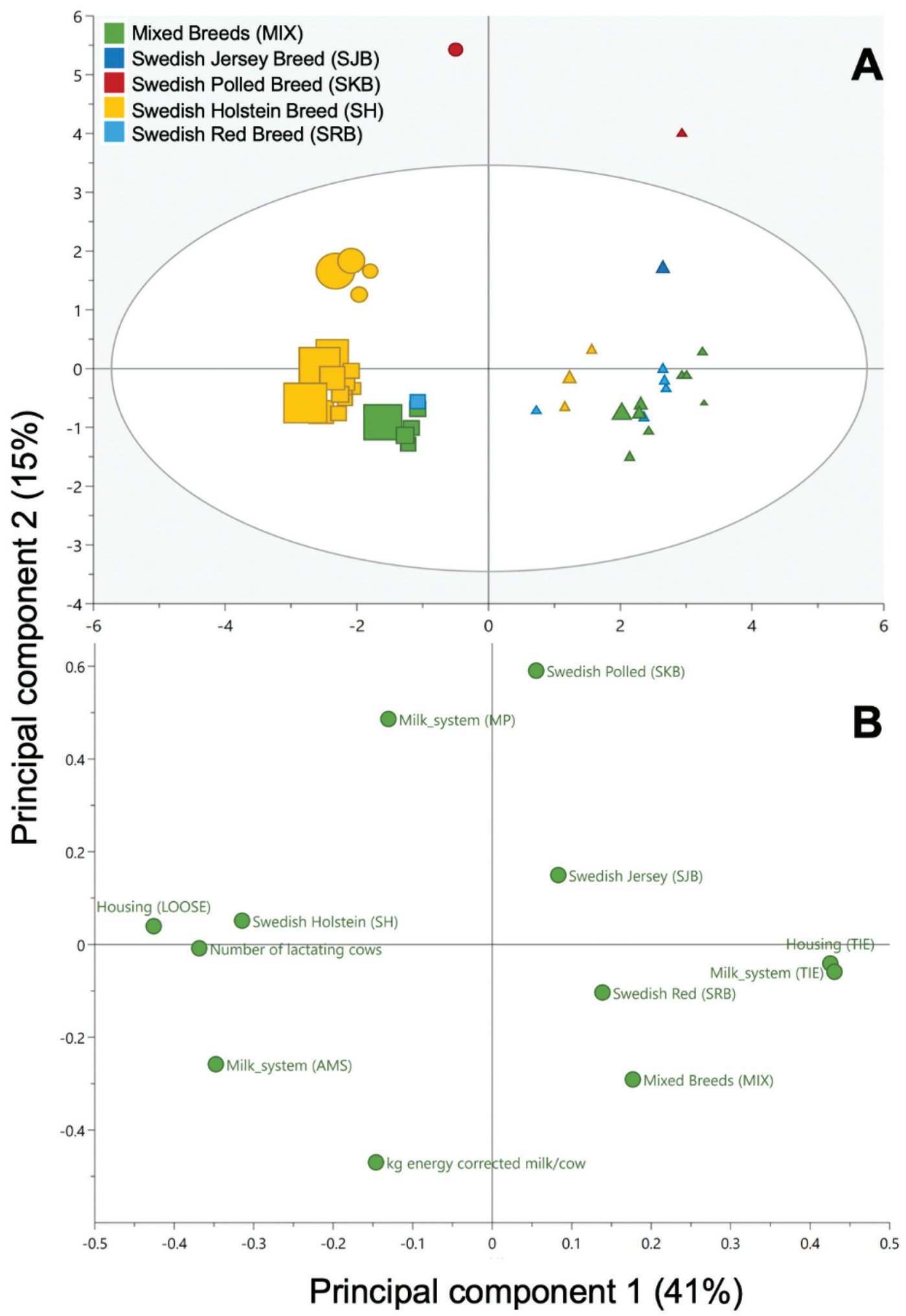

Figure 2. Principal component analysis (PCA) score plot (A) and loading plot (B) of selected on-farm factors documented on participating farms. In the score plot, each symbol represents an individual farm, with color indicating dominant breed, and shape indicating the milking system. Square = automatic milking system $(\mathrm{AMS})$, circle $=$ milking parlor $(\mathrm{MP})$, triangle = tiestall milking system $(\mathrm{TIE})$. Symbol size indicates the number of lactating cows in the herd. 


\section{RESULTS AND DISCUSSION}

\section{Variation in On-Farm Factors Between Participating Farms}

The variation associated with on-farm factors was studied using data collected from the questionnaire, farm visits, and the Swedish cow-recording scheme (Kokontrollen, 2016). Data included in this study are listed in Supplemental File S1 (https://dataverse .harvard.edu/dataset.xhtml?persistentId=doi:10.7910/ DVN/WKFDIJ). From the preliminary multivariate screening of farm and milk data (Figure 1), the following farm factors were considered in the future models: (1) dominant breed (defined as the breed comprising $>70 \%$ of the total herd), (2) milking system (AMS, tiestall, or milking parlor), (3) housing (tied or loose), (4) number of lactating cows, and (5) ECM yield (kg) per cow. Differences in milk quality attributes between organic $(\mathrm{n}=5)$ and conventional $(\mathrm{n}=37)$ farms were not observed in this study (Supplemental File S2, https: //dataverse.harvard.edu/dataset.xhtml?persistentId= doi:10.7910/DVN/BPJEC5), which is likely explained by similarities between the production systems (i.e., breeds and milking system).

The dominant breed on most farms was $\mathrm{SH}$ (19 farms), whereas Swedish Jersey (SJB) was only reported as dominant on 1 of the participating farms. These figures correspond well with data in the Swedish official cow-recording scheme (Växa Sverige, 2017) and with findings by Frössling et al. (2017), who reported $\mathrm{SH}$ to be the most common breed ( $50 \%$ of the dairy cow population in Sweden), followed by Swedish Red (SRB; 44\%). In contrast, SJB and Swedish Polled (SKB) are rare dairy breeds in Sweden (Växa Sverige, 2017). Considering the low number of farms reporting SJB and SKB as the dominant breed in their herd, results on composition and properties of milk from these cows must be interpreted with caution.

The proportions of AMS ( $42 \%$ of farms) and tiestall milking ( $45 \%$ of farms) among participating farms reflect a situation where AMS is being increasingly installed on dairy farms. In 2018, the total proportion of farms in the region using AMS was 34\%, in comparison with $28.7 \%$ on a national level (Växa Sverige, 2017). This suggests that the change from conventional milking to AMS has been more intense in the investigated region in comparison with the rest of Sweden. Daily milk yield (ECM) was 32.1, 29.6, and $29.2 \mathrm{~kg}$ in AMS, MP, and tiestall herds, respectively (Table 1). The average herd size $(\mathrm{n}=66$ lactating cows $)$ and annual milk yield $(9,806 \mathrm{~kg}$ of ECM per cow) in participating farms were also representative of northern Sweden (Växa Sverige, 2017).
Using PCA to assess the variation associated with the selected on-farm factors, 2 major groups of farms were identified based on principal component 1 (Figure 2 ). One cluster consisted of tiestall farms with various breeds in the herd, and the other cluster of farms with loose housing and milking parlor or AMS, with $\mathrm{SH}$ as the dominant breed $(73.8 \%$ and $75.8 \%$ of $\mathrm{SH}$ in herds using milking parlor and AMS, respectively; Table 1). A higher number of lactating cows (i.e., larger farms) was strongly associated with $\mathrm{SH}$ as the dominant breed, loose housing, and AMS ( $\sim 85$ cows) and milking parlor (approximately 86 cows), whereas tiestall farms were smaller ( $\sim 30$ cows; Figure 2$)$. In tiestall farms, SRB and SH percentages were 47.4 and 30.8 , respectively (Table 1). The selected farm factors (milking system, housing system, number of lactating cows, ECM yield, and breed) were clearly confounded. This must be kept in mind when assessing the effect of individual on-farm factors on milk quality attributes (e.g., milking system or dominant breed in the herd).

\section{Variation in Milk Quality Attributes Associated With Farm Type}

The variation in the analyzed quality attributes of the milk samples is illustrated in the PCA plots in Figure 3. There was a clear effect of farm type on milk quality attributes, illustrated in Figure 3A by the color of the dots. Although there were exceptions, milk samples from farms with tiestall milking were mainly located to the left on principal component 1 , milk samples from farms with AMS more to the right, and milk samples from farms with milking parlors in intermediate positions (Figure 3A). This distribution can be attributed to differences in milk composition, as visualized in the loading plot (Figure 3B). The PCA suggested that milk from farms with tiestall milking, where the dominant breed was SRB but also mixtures of breeds were common, was associated with a higher fat and protein content, but a lower lactose content, in contrast to milk from farms with AMS and MP, where the dominant breed was SH. This is illustrated in Supplemental File S3 (https://dataverse.harvard. edu/dataset.xhtml?persistentId=doi:10.7910/DVN/ YLFI4T) by coloring the score plot in Figure 3 according to the 2 dominant breeds (SRB and $\mathrm{SH}$ ). These results agree with the previous finding by Wedholm et al. (2006), where fat and protein contents are higher in milk from SRB compared with SH cows, and also comply with the national data (Växa Sverige, 2017).

As mentioned, herd size, breed, housing system, and milking system were confounding factors in this case study. It is well known that cow breed is linked to several milk properties, such as fat and protein content. 
Priyashantha et al.: EFFECT OF DAIRY FARMING SYSTEM ON MILK QUALITY

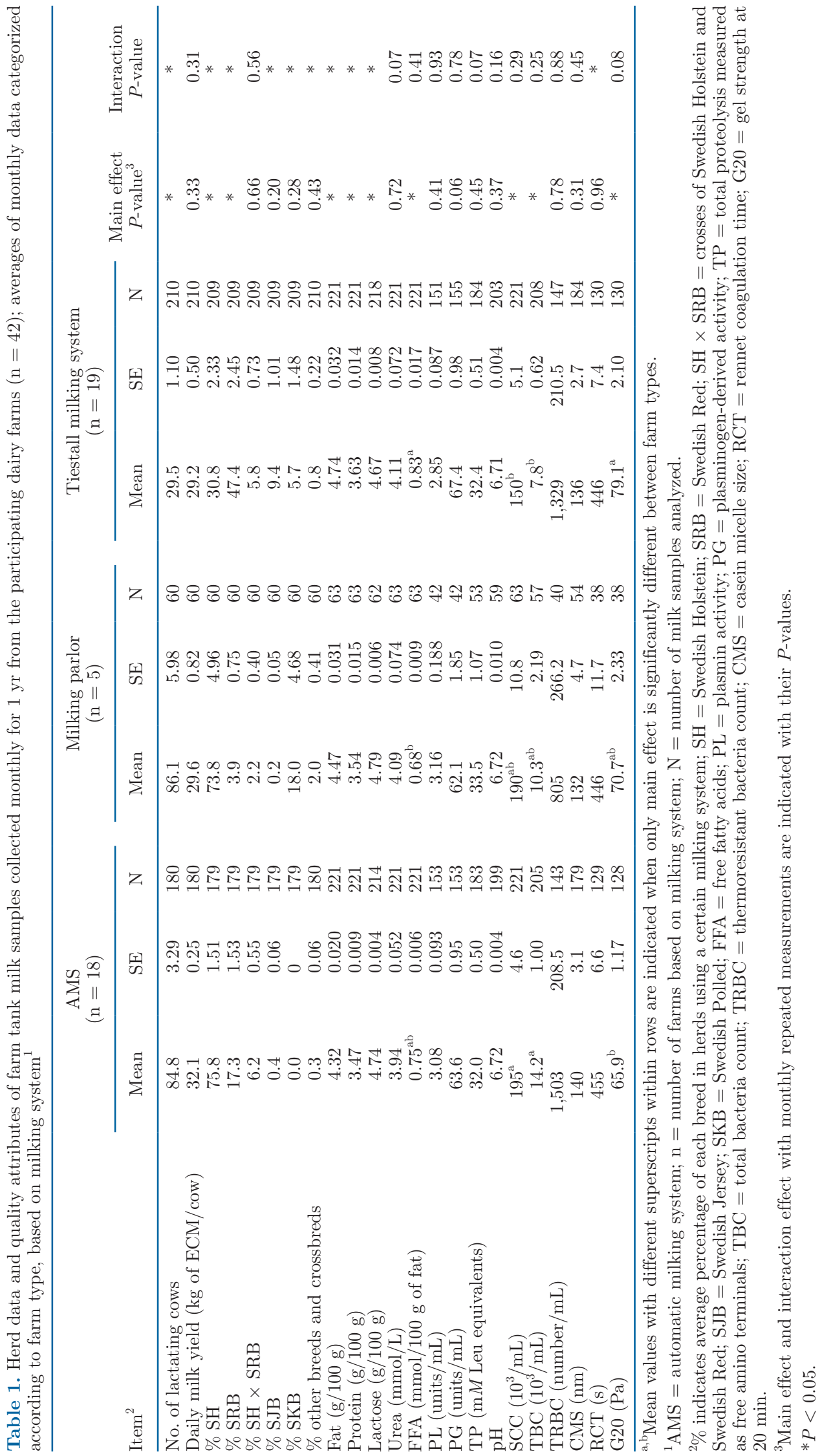




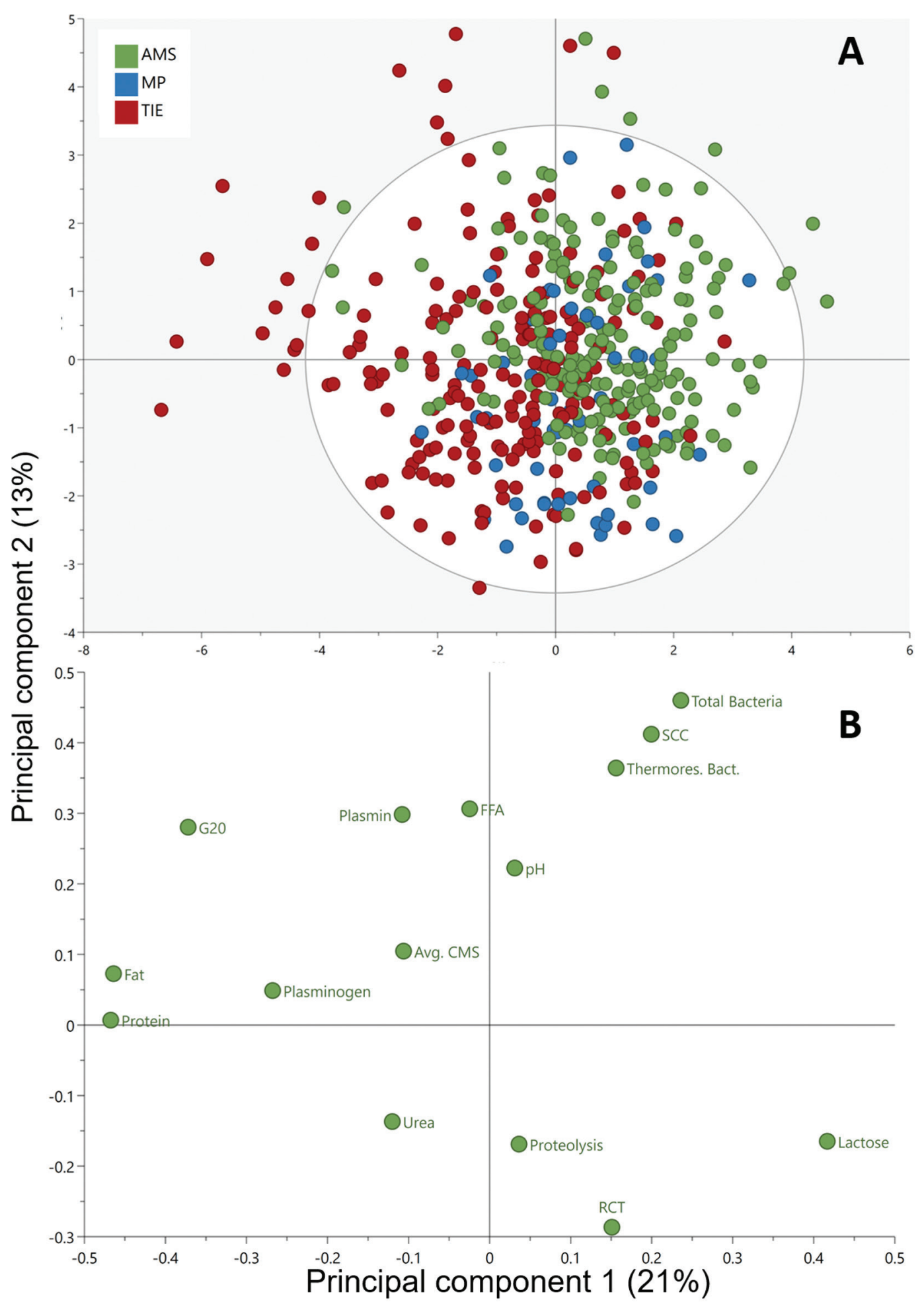

Figure 3. Principal component analysis score plot (A) and loading plot (B) of milk quality attributes (monthly data per farm). In the score plot, each dot represents a milk sample, and dot color indicates the milking system on the farm. AMS = automatic milking system; MP $=$ milking parlor; TIE = tiestall milking. In Supplemental File S3 (https://dataverse.harvard.edu/dataset.xhtml?persistentId=doi:10.7910/DVN/ YLFI4T), score plots are colored according to the prevalence of the 2 major breeds (Swedish Red and Swedish Holstein). 
Because the breed distribution on the participating farms was closely associated with housing and milking systems, these factors were expected to contribute to the observed differences to various extent; however, the effects of the individual factors cannot always be separated in our study. Descriptive data for the milk quality attributes in monthly samples, categorized according to the milking system and dominant breed, are shown in Tables 1 and 2, respectively.

As can be seen in Table 1, despite the significant interaction, there were differences in fat and protein content between milking systems, with higher values observed for tiestall compared with AMS or milking parlor farms. Milking frequency has previously been found to be negatively correlated with fat and protein content (e.g., Svennersten-Sjaunja et al., 2007; Løvendahl and Chagunda, 2011). In a comparison of tank milk from commercial Swedish dairy farms with conventional or robotic milking systems, Johansson et al. (2017) reported lower fat and protein content in milk from AMS than in milk from MP, which they attributed to the higher milking frequency in AMS. The daily milking frequency on AMS farms in this study was on average 2.7, and farms with tiestalls or milking parlors 2.0, according to questionnaire responses. Therefore, lower milking frequency in tiestall or milking parlor systems compared with AMS likely contributed to the observed difference in fat and protein contents. However, the compositional differences were most likely also linked to the higher occurrence of breeds that yield higher fat and protein content in milk from tiestall farms (Table 1,2), and SH as the dominant breed on AMS farms (Figure 2). Despite the significant interactions, milk from herds with SRB cows showed numerically higher $(P=0.07)$ protein and fat percentage (3.66\% and $4.85 \%$, respectively) compared with milk from herds with $\mathrm{SH}$ as the dominant breed $(3.55 \%$ and $4.33 \%$, respectively; Table 2). Likewise, Bieber et al. (2019) and Wedholm et al. (2006) reported that milk from SRB contained higher fat and protein than milk from SH. The nonsignificant differences in the present study may be due to the fact that we used herd milk samples where one breed may be dominant, but not the only breed contributing to the farm milk sample. Milk from the farm with SJB as the dominant breed had the highest protein and fat content of all farms $(4.06 \%$ and $6.21 \%$, respectively).

Despite the significant interaction, lactose levels were lower in milk from SRB than in milk from $\mathrm{SH}$ in this study (Table 2). Likewise, Wedholm et al. (2006) found a significantly higher lactose content in milk from $\mathrm{SH}$ than in milk from SRB cows, whereas there was no difference when milk from SH and Danish Holstein cows were compared. Because results for SJB and SKB were based on only 1 and 2 herds, respectively, one should be cautious with too long-reaching interpretations. The lowest lactose content was in milk from the SJB farm. Considering that SJB cows produce two-thirds of the amount of milk compared with SH cows (Växa Sverige, 2017), the lower lactose content in milk from Jersey was expected. However, the highest lactose content was found in milk from the 2 farms with SKB cows. This is difficult to explain because SKB cows produce even less milk than SJB cows, averaging $54 \%$ of an SH cow (Växa Sverige, 2017). However, milk yield is not only governed by lactose concentration but also many other factors (e.g., genetics, feed, nutrition, metabolism, parity, and stage of lactation; McGuffey, 2017).

An elevated level of FFA in milk, resulting from enzymatic degradation of milk fat, is undesirable because it may confer a rancid taste to the final product (McSweeney et al., 1997). Irrespective of breed or milking system, FFA values in the present study were generally low (0.68-0.83 mmol/100 g of fat, Table 1) compared with values reported by Wiking et al. (2006), who investigated the effect of milking frequency on FFA levels in milk from SRB cows. The lowest FFA level in their study, $0.72 \mathrm{mEq} / 100 \mathrm{~g}$ of fat, was found when cows were milked twice per day and milk samples were analyzed immediately after milking. The FFA content in milk has been reported to be positively correlated with higher milking frequency (Klungel et al., 2000; Wiking et al., 2006). A suggested explanation for this is the disruption of the milk fat globule membrane as a result of mechanical stress in AMS and exposure of triglycerides to lipase (Hogenboom et al., 2019). Therefore, we expected higher FFA content to be associated with milk from AMS farms in our study. In fact, we found that milk from tiestall farms had higher numerical FFA content than milk from AMS farms (Table 1). It is difficult to suggest an explanation for this unexpected result. The results could also be related to factors associated with the status of the milking equipment on the farms (e.g., age and function) because higher FFA values were mostly reported from the oldest and smallest barns in our study, which all belonged to tiestalls farms. There are also studies reporting that no differences in FFA levels in milk from farms with AMS, MP, or tiestall milking (e.g., Johansson et al., 2017). Factors reported to contribute to variation in FFA levels include differences in mechanical treatment of the raw milk between farms with tiestall milking systems and AMS (e.g., pumping, foaming, and posthandling time; de Koning et al., 2003). The individual farm factor likely contributes to the fact that varying results on FFA in milk from different milking systems are reported.

For certain types of long-ripening cheeses, plasmin plays an important role in protein degradation during 
Priyashantha et al.: EFFECT OF DAIRY FARMING SYSTEM ON MILK QUALITY

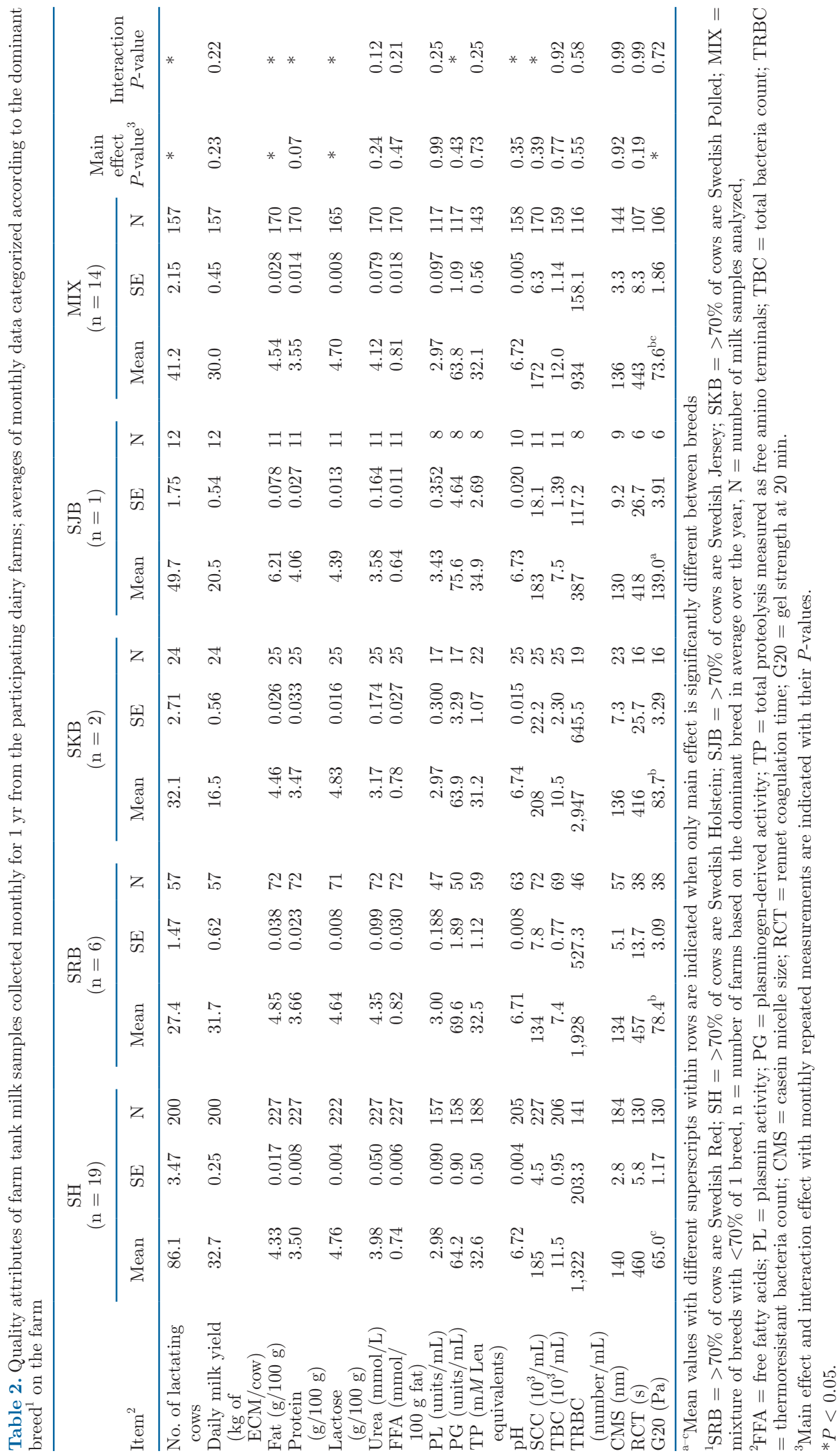


cheese maturation (Ismail and Nielsen, 2010). This was the reason for including analysis of plasmin and plasminogen-derived activity in raw milk and investigating causes of its variation in this study. The average plasmin activity in tank milk was $3.08,3.16$, and $2.85 \mathrm{U} / \mathrm{mL}$ for farms with AMS, MP, and tiestall, and plasminogen activity was 63.6, 62.1, and $67.4 \mathrm{U} / \mathrm{mL}$, respectively. In contrast to Johansson et al. (2017), we found no significant differences in plasmin activity when comparing milk from farms with different milking systems (Table 1), and no differences between farms with different dominant breeds (Table 2). Likewise, Bastian et al. (1991) found no differences in plasmin activity between breeds in milk samples collected monthly from Holstein and Jersey cows during 10 mo of lactation. Those authors concluded that lactation number (parity) had the greatest influence on plasmin activity, with higher plasmin activity in milk from cows in their fourth and later lactations. We did not observe any effect of the milking system (Table 1) or breed (Table 2) on plasminogen or total proteolysis, measured as free amino terminals, in milk in the present study.

The average SCC was low from an international perspective, but it was higher in milk from AMS farms than in milk from farms using a tiestall milking system in this study (Table 1). Likewise, although average total bacteria counts were very low in farm tank milk $\left(7.8-14.210^{3} / \mathrm{mL}\right)$, significantly higher levels were observed in milk from herds with AMS than in milk from herds with tiestall milking (Table 1). In a review, Svennersten-Sjaunja and Pettersson (2008) discussed the reasons for the observed increase in SCC and total bacteria numbers in milk after introducing AMS in Europe. Higher SCC was suggested to be linked to several factors, some related to AMS per se (e.g., variation in the length of milking interval), whereas other factors were related to herd management on AMS farms. Using data from the Swedish Official Milk Recording Scheme, Frössling et al. (2017) also showed that a higher incidence of elevated SCC was associated with milk from AMS farms. Persson Waller et al. (2009), reported that milk from SRB cows had lower SCC compared with SH milk due to better udder health, inherent mastitis resistance, and efficient immune defense. In the present study, a probable reason for not observing differences in SCC between breeds could be that this study used tank milk samples classified according to the dominant breed in the herd, not individual cow milk samples. The fact that breed and milking system were confounding factors, with $\mathrm{SH}$ commonly being the dominant breed on AMS and milking parlor farms (Figure 1), likely explained the higher numbers of SCC in milk from AMS herds compared with farms with tiestall milking, and that milk from milking parlor farms showed numbers between the other 2 systems.

The total number of bacteria in milk is known to be associated with microbial contamination from the exterior of the udder, cleaning and sanitizing practices, and raw milk storage temperature and time (Bramley and Mckinnon, 1990). Mastitis pathogens are also known to contribute to the total bulk milk bacteria count, and cows with mastitis shed more bacteria into the milk than healthy cows (Bramley and Mckinnon, 1990). Fenlon et al. (1995) suggested that a mammary infection caused by mastitis pathogens will give rise to an increase in SCC as well as in total bacteria count in the milk. In the literature, the SRB breed is associated with a lower incidence of veterinary-treated clinical cases of mastitis compared with $\mathrm{SH}$ cows (Nyman et al., 2007; Bieber et al., 2019). This may be in line with the numerically lower total bacteria counts in milk from SRB cows compared with milk from $\mathrm{SH}$ cows in this study. There was no significant effect of the milking system or breed on the number of thermoresistant bacteria. The low number found in SJB milk and the high number in SKB milk was probably a consequence of these breeds being represented by only 1 and 2 farms, respectively (Table 2).

In the present study, we observed no significant difference in casein micelle size when comparing milk from farms with different milking systems (Table 1) or breeds (Table 2); we only found differences in numerical values, with larger casein micelles in milk from farms with SH compared with SRB as a dominant breed (Table 2). This agrees with Glantz et al. (2010), who found that milk from SH cows had a larger average casein micelle size $(200 \mathrm{~nm})$ than milk from SRB cows $(191 \mathrm{~nm})$. The differences in numerical values between our study and the study by Glantz et al. (2010) are likely explained by the different measuring techniques applied [i.e., NTA in our study and dynamic light scattering in the study by Glantz et al. (2010)].

Milk coagulation properties, measured as G20, were influenced particularly by breed, where milk from the SJB farm had an average G20 of $139 \mathrm{~Pa}$, in comparison with $65.0 \mathrm{~Pa}$ for milk from farms with $\mathrm{SH}$ as the dominant breed (Table 2). Likewise, Jensen et al. (2012) found that milk from the Jersey breed had superior coagulation properties compared with milk from Holstein-Friesian cows, likely explained by the higher protein content (4.49 g/100 g), and specifically a high total casein content $(3.13 \mathrm{~g} / 100 \mathrm{~g})$, in Jersey milk. Frederiksen et al. (2011) showed that milk from Jersey cows exhibited superior coagulation properties to milk from Danish Red or Danish Holstein-Friesian, owing to higher protein content $(3.81 \mathrm{~g} / 100 \mathrm{~g})$ in Jer- 
sey milk compared with milk from the other 2 breeds (3.52 and $3.47 \mathrm{~g} / 100 \mathrm{~g}$, respectively). The effect of the breed was also significant when comparing G20 for the different milking systems in our study (Table 1). Milk from farms with tiestall milking systems, which was positively associated with breeds other than SH (Figure 1), had a significantly higher G20 value than milk from farms with AMS or MP. Moreover, the difference in G20 might also result from the lower protein and fat content associated with higher milking frequency in AMS as observed in the present study, in agreement with Løvendahl and Chagunda (2011). In contrast, the milking system or breed did not affect RCT. Rennet coagulation time and G20 are generally inversely related; milk that coagulates rapidly (low RCT) has higher gel strength (high G20). This is visualized in the PCA in Figure 3B, where RCT and G20 are located on opposite sides in the loading plot, previously also reported by Priyashantha et al. (2019). Hallén et al. (2007) investigated the rheological properties of individual milk samples from SRB and SH and observed that protein concentration was positively associated with G20, but not with RCT, also confirming our observations. Problems previously reported to be associated with milk from SRB cows [e.g., noncoagulating properties and significantly lower gel strength in milk from individual cows (Frederiksen et al., 2011; Nilsson et al., 2019) and also in farm milk (Gustavsson et al., 2014)] were not evident in our study.

\section{CONCLUSIONS}

Two types of dairy farming systems were distinguished in this study (i.e., larger farms with AMS or milking parlors with $\mathrm{SH}$ as the dominant breed, and smaller tiestall farms with other breeds than Holstein). The shift toward larger farms is an effect of the structural dairy intensification that has gone on for some time in the investigated region. The continuous change in dominant breed, housing, and milking system, and the increasing herd size has most likely influenced the raw milk properties, and thus the following dairy processing. The type of dairy farming system showed a significant effect on many of the investigated milk quality traits. Because the housing and milking systems and dominant breed in the herd were confounding factors, it was difficult to distinguish their individual effects on milk quality attributes in this case study. Overall, we found that milk produced in the region was of high quality, irrespective of the dominant breed or milking system. To gain deeper insights into causes for the variation in raw milk, the influence of individual on-farm factors would need to be investigated further. Studies on the effects of raw milk variation as influenced by on-farm factors on cheese ripening are ongoing.

\section{ACKNOWLEDGMENTS}

This study was conducted with financial support from the Swedish Farmers' Foundation for Agricultural Research (Stockholm, Sweden; grant number O-16-20764), the Kamprad Family Foundation (Växjö, Sweden; grant number 20160098), the Regional Fund for Agricultural Research in Northern Sweden (Umeå, Sweden grant number 4/2015), and the Faculty of Natural Resources and Agriculture, SLU (Uppsala, Sweden). Last, we thank all the dairy farmers who participated in this study. The authors have not stated any conflicts of interest.

\section{REFERENCES}

Bastian, E. D., R. J. Brown, and C. A. Ernstrom. 1991. Plasmin activity and milk coagulation. J. Dairy Sci. 74:3677-3685. https://doi .org/10.3168/jds.S0022-0302(91)78557-3.

Bieber, A., A. Wallenbeck, F. Leiber, B. Fuerst-Waltl, C. Winckler, P. Gullstrand, J. Walczak, P. Wójcik, and A. S. Neff. 2019. Production level, fertility, health traits, and longevity in local and commercial dairy breeds under organic production conditions in Austria, Switzerland, Poland, and Sweden. J. Dairy Sci. 102:5330 5341. https://doi.org/10.3168/jds.2018-16147.

Bramley, J. A., and H. C. Mckinnon. 1990. The microbiology of raw milk. Pages 163-208 in Dairy Microbiology, Vol. 1. R. K. Robinsson, ed. Elsevier Applied Sciences.

Clay, N., T. Garnett, and J. Lorimer. 2020. Dairy intensification: Drivers, impacts and alternatives. Ambio 49:35-48. https://doi.org/10 .1007/s13280-019-01177-y.

de Koning, K., B. Slaghuis, and Y. van der Vorst. 2003. Robotic milking and milk quality: Effects on bacterial counts, somatic cell counts, freezing point and free fatty acids. Ital. J. Anim. Sci. 2:291-299. https://doi.org/10.4081/ijas.2003.291.

De Marchi, M., M. Penasa, and M. Cassandro. 2017. Comparison between automatic and conventional milking systems for milk coagulation properties and fatty acid composition in commercial dairy herds. Ital. J. Anim. Sci. 16:363-370. https://doi.org/10.1080/ 1828051X.2017.1292412.

de Vries, R., M. Brandt, A. Lundh, K. Holtenius, K. Hettinga, and M. Johansson. 2016. Short communication: Influence of shortening the dry period of Swedish dairy cows on plasmin activity in milk. J. Dairy Sci. 99:9300-9306. https://doi.org/10.3168/jds.2016 -11502 .

Fenlon, D. R., D. N. Logue, J. Gunn, and J. Wilson. 1995. A study of mastitis bacteria and herd management practices to identify their relationship to high somatic cell counts in bulk tank milk. Br. Vet. J. 151:17-25. https://doi.org/10.1016/S0007-1935(05)80059-4.

Frederiksen, P. D., M. Hammershøj, M. Bakman, P. N. Andersen, J. B. Andersen, K. B. Qvist, and L. B. Larsen. 2011. Variations in coagulation properties of cheese milk from three Danish dairy breeds as determined by a new free oscillation rheometry-based method. Dairy Sci. Technol. 91:309-321. https://doi.org/10.1007/ s13594-011-0018-5.

Frössling, J., A. Ohlson, and C. Hallén-Sandgren. 2017. Incidence and duration of increased somatic cell count in Swedish dairy cows and associations with milking system type. J. Dairy Sci. 100:73687378. https://doi.org/10.3168/jds.2016-12333.

Glantz, M., T. G. Devold, G. E. Vegarud, H. Lindmark Månsson, H. Stålhammar, and M. Paulsson. 2010. Importance of casein micelle 
size and milk composition for milk gelation. J. Dairy Sci. 93:14441451. https://doi.org/10.3168/jds.2009-2856.

Guinee, T. P., and B. O'Brien. 2010. The Quality of Milk for Cheese Manufacture. Pages 1-67 in Technology of Cheesemaking. B. A. Law and A. Y. Tamine, ed. John Wiley \& Sons.

Gustavsson, F., A. J. Buitenhuis, M. Glantz, H. Stålhammar, H. Lindmark-Månsson, N. A. Poulsen, L. B. Larsen, A. Andrén, and M. Paulsson. 2014. Impact of genetic variants of milk proteins on chymosin-induced gelation properties of milk from individual cows of Swedish Red dairy cattle. Int. Dairy J. 39:102-107. https://doi .org/10.1016/j.idairyj.2014.05.007.

Hallén, E., T. Allmere, J. Näslund, A. Andrén, and A. Lundén. 2007. Effect of genetic polymorphism of milk proteins on rheology of chymosin-induced milk gels. Int. Dairy J. 17:791-799. https://doi .org/10.1016/j.idairyj.2006.09.011.

Hogenboom, J. A., L. Pellegrino, A. Sandrucci, V. Rosi, and P. D'Incecco. 2019. Invited review: Hygienic quality, composition, and technological performance of raw milk obtained by robotic milking of cows. J. Dairy Sci. 102:7640-7654. https://doi.org/10 $.3168 /$ jds.2018-16013.

Ismail, B., and S. S. Nielsen. 2010. Invited review: Plasmin protease in milk: Current knowledge and relevance to dairy industry. J. Dairy Sci. 93:4999-5009. https://doi.org/10.3168/jds.2010-3122.

Jackson, J. E. 1991. A Use's Guide to Principal Components. John Wiley \& Sons, Ltd.

Jensen, H. B., N. A. Poulsen, K. K. Andersen, M. Hammershøj, H. D. Poulsen, and L. B. Larsen. 2012. Distinct composition of bovine milk from Jersey and Holstein-Friesian cows with good, poor, or noncoagulation properties as reflected in protein genetic variants and isoforms. J. Dairy Sci. 95:6905-6917. https://doi.org/10.3168/ jds.2012-5675.

Johansson, M., M. Högberg, and A. Andrén. 2015. Relation between $\alpha_{S 1}$-casein content and coagulation properties of milk from Swedish dairy goats. Open Food Sci. J. 9:1-4. https://doi.org/10.2174/ 1874256401509010001.

Johansson, M., Å. Lundh, R. de Vries, and K. S. Sjaunja. 2017. Composition and enzymatic activity in bulk milk from dairy farms with conventional or robotic milking systems. J. Dairy Res. 84:154-158. https://doi.org/10.1017/S0022029917000140.

Kailasapathy, K. 2015. Chemical Composition, Physical, and Functional Properties of Milk and Milk Ingredients. Pages 77-105 in Dairy Processing and Quality Assurance. R. C. Chandan, A. Kilara, and N. P. Shah, ed. John Wiley \& Sons, Ltd.

Klungel, G. H., B. A. Slaghuis, and H. Hogeveen. 2000. The effect of the introduction of automatic milking systems on milk quality. J. Dairy Sci. 83:1998-2003. https://doi.org/10.3168/jds.S0022 $-0302(00) 75077-6$

Kokontrollen. 2016. Swedish Official Milk Recording Scheme, "Kokontrollen." Växa Sverige. Accessed Jul. 1, 2020. https://www.vxa.se/ globalassets/dokument/statistik/husdjursstatistik2016.pdf.

Løvendahl, P., and M. G. G. Chagunda. 2011. Covariance among milking frequency, milk yield, and milk composition from automatically milked cows. J. Dairy Sci. 94:5381-5392. https://doi.org/10 $.3168 /$ jds.2010-3589.

McGuffey, R. K. 2017. A 100-Year Review: Metabolic modifiers in dairy cattle nutrition. J. Dairy Sci. 100:10113-10142. https://doi .org/10.3168/jds.2017-12987.

McSweeney, P. L. H., H. E. Nursten, and G. Urbach. 1997. Flavours and off-flavours in milk and dairy products. Pages 403-468 in Advanced Dairy Chemistry Volume 3: Lactose, Water, Salts and Vitamins. P. F. Fox, ed. Springer.

Nilsson, K., H. Stålhammar, M. Stenholdt Hansen, H. LindmarkMånsson, S. Duchemin, F. Fikse, D. J. de Koning, M. Paulsson, and M. Glantz. 2019. Characterisation of non-coagulating milk and effects of milk composition and physical properties on rennet- induced coagulation in Swedish Red Dairy Cattle. Int. Dairy J. 95:50-57. https://doi.org/10.1016/j.idairyj.2019.03.006.

Nyman, A.-K., T. Ekman, U. Emanuelson, A. H. Gustafsson, K. Holtenius, K. P. Waller, and C. H. Sandgren. 2007. Risk factors associated with the incidence of veterinary-treated clinical mastitis in Swedish dairy herds with a high milk yield and a low prevalence of subclinical mastitis. Prev. Vet. Med. 78:142-160. https://doi.org/ 10.1016/j.prevetmed.2006.10.002.

Persson Waller, K., B. Bengtsson, A. Lindberg, A. Nyman, and $\mathrm{H}$. Ericsson Unnerstad. 2009. Incidence of mastitis and bacterial findings at clinical mastitis in Swedish primiparous cows - Influence of breed and stage of lactation. Vet. Microbiol. 134:89-94. https:// doi.org/10.1016/j.vetmic.2008.09.004.

Priyashantha, H., A. Höjer, K. H. Saedén, Å. Lundh, M. Johansson, G. Bernes, P. Geladi, and M. Hetta. 2020. Use of near-infrared hyperspectral (NIR-HS) imaging to visualize and model the maturity of long-ripening hard cheeses. J. Food Eng. 264:109687. https:// doi.org/10.1016/j.jfoodeng.2019.109687.

Priyashantha, H., À. Lundh, A. Höjer, G. Bernes, D. Nilsson, M. Hetta, K. H. Saedén, A. H. Gustafsson, and M. Johansson. 2021. Composition and properties of bovine milk: A study from dairy farms in northern Sweden; Part II. Effect of monthly variation. J. Dairy Sci. 104:8595-8609. https://doi.org/10.3168/jds.2020-19651.

Priyashantha, H., Å. Lundh, A. Höjer, M. Hetta, M. Johansson, and M. Langton. 2019. Interactive effects of casein micelle size and calcium and citrate content on rennet-induced coagulation in bovine milk. J. Texture Stud. 50:508-519. https://doi.org/10.1111/ jtxs. 12454

Skeie, S. 2007. Characteristics in milk influencing the cheese yield and cheese quality. J. Anim. Feed Sci. 16(Suppl. 1):130-142. https:// doi.org/10.22358/jafs/74164/2007.

Svennersten-Sjaunja, K. M., and G. Pettersson. 2008. Pros and cons of automatic milking in Europe. J. Anim. Sci. 86(suppl_13):37-46. https://doi.org/10.2527/jas.2007-0527.

Svennersten-Sjaunja, K. M., L. Wiking, A. Edvardsson, A.-K. Båvius, L. B. Larsen, and J. H. Nielsen. 2007. Effect of frequent milking on milk fat and protein. J. Anim. Feed Sci. 16(Suppl. 1):151-155. https://doi.org/10.22358/jafs/74167/2007.

Växa Sverige. 2017.Växa Sverige, 2017. Husdjursstatistik / cattle statistics. Accessed Jul. 1, 2020. https://www.vxa.se/globalassets/ dokument/statistik/husdjursstatistik_2017.pdf.

Wedholm, A., E. Hallén, L. B. Larsen, H. Lindmark-Månsson, A. H. Karlsson, and T. Allmere. 2006. Comparison of milk protein composition in a Swedish and a Danish dairy herd using reversed phase HPLC. Acta Agric. Scand. Sect. A Anim. Sci. 56:8-15. https://doi .org/10.1080/09064700600836745.

Wehr, H. M., and J. F. Frank. 2004. Standard Methods for the Examination of Dairy Products. American Public Health Association.

Wiking, L., M. Bjerring, M. M. Løkke, P. Løvendahl, and T. Kristensen. 2019. Herd factors influencing free fatty acid concentrations in bulk tank milk. J. Dairy Res. 86:226-232. https://doi.org/ 10.1017/S0022029919000190.

Wiking, L., M. B. Frøst, L. B. Larsen, and J. H. Nielsen. 2002. Effects of storage conditions on lipolysis, proteolysis and sensory attributes in high quality raw milk. Milchwissenschaft 57:190-194.

Wiking, L., J. H. Nielsen, A.-K. Båvius, A. Edvardsson, and K. Svennersten-Sjaunja. 2006. Impact of milking frequencies on the level of free fatty acids in milk, fat globule size, and fatty acid composition. J. Dairy Sci. 89:1004-1009. https://doi.org/10.3168/ jds.S0022-0302(06)72166-X.

Wold, S., K. Esbensen, and P. Geladi. 1987. Principal component analysis. Chemom. Intell. Lab. Syst. Pages 37-52 in Proceedings of the Multivariate Statistical Workshop for Geologists and Geochemists 2. Elsevier. 